\title{
Analyzing Students' Voice of Using Semantic Mapping Technique in Oral Presentation Class
}

\author{
Isry Laila Syathroh \\ Faculty of Language Education, English Education Program of IKIP Siliwangi \\ Cimahi, Indonesia \\ E-mail: islaisya@yahoo.com
}

\begin{abstract}
Oral presentation skill is one of the crucial skills which should be possessed by students in higher education. Students are expected to be able to express their ideas and show their understanding of the subject matter, either in verbal or non-verbal communication. Semantic mapping is a strategy which can be used to manage ideas in delivering topics of oral presentation. Therefore, the aim of this study is to explore what students perceive the use of semantic mapping in their oral presentation class. Thirty students were involved in this study. They joined 800 minutes of Teaching English to Young Learners (TEYL) subject. They should read and report what they have read orally through group presentations. Their oral presentation skills were assessed based on four aspects: quality of information and organization, quality of non-verbal communication, visual tools, appropriate use of terminology, as well as precision and details in the document produced. At the end of the course, it was revealed that the use of semantic mapping could help students in giving an effective oral presentation. It can improve students' performance in oral presentation project by enhancing the quality of presentation criteria aforementioned above. The result of the questionnaire also revealed that students positively perceive the use of semantic mapping when giving an oral presentation. They claim that the use of semantic mapping is beneficial for them for giving an effective oral presentation.
\end{abstract}

Keywords: oral presentation, semantic mapping, students' perception, TEYL

\section{INTRODUCTION}

An oral presentation is one of the most popular teachings and learning strategies in an educational institution, especially in a higher education context. Teachers usually ask their students to do oral presentation either individually or in groups to assess their communication skills. From students' point of view, an oral presentation is also needed to give them the opportunity to practice the language in situations which encourage them to communicate their needs, ideas and opinions. In order to possess effective oral communication, students need a thorough, in-depth instruction and practice.

Beyond the learning process in the university context, oral communication skill is also vital for students' future life, such as in job interview or job recruitments. Murphy and Hildebrand (1997) claim that effective oral communication is essential for success and promotion in business. Thus, oral presentation skills are essential for employability 
and proper academic study as they lead students to enter into debate and sustained reasoning (Morley, 2001). It is in accordance with what Živković \& Stojković (2011) that with globalization, graduates need to be proficient in oral communication skills in order to function effectively in the professional setting.

Concerning curriculum in higher education, using oral presentations at university level is an especially relevant curriculum segment and is done with the ultimate purpose of better communicating professional knowledge to other professionals and nonspecialists (Živković \& Stojković, 2011). Every professional is involved in some aspects of communication, which usually involve gathering, analyzing, and distributing scientific and technical information efficiently and accurately for specific audiences. The results are substantive, which means improving the quality of the presentation improves the quality of thought and vice versa. Students can gain knowledge not only from the research they and other students perform but also by observing the other presenters' strengths and weaknesses to develop better communication and presentation skills" (Girard \& Trapp, 2011).

Using oral presentation in the teaching-learning process offers many benefits. Girard \& Trapp (2011) explains that oral presentation can promote more significant class interaction as well as students' learning interests and participation. Additionally, King (2002) claims oral presentation can represent an opportunity for developing realworld communications as well as leadership skills. Figure 1 below displays the benefits of oral presentation elaborated by King (2002):

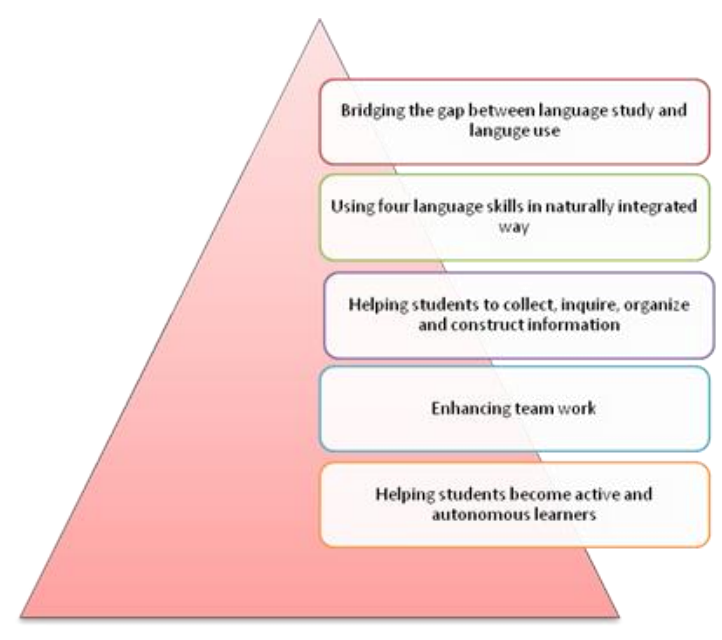

Figure 1: Benefits of Oral Presentation (King, 2002) 
Many strategies can be done to give an effective oral presentation. One of them is using semantic mapping. Semantic mapping technique is usually defined as a visual strategy for extension of knowledge by displaying in categories words related to one another. It can be done by drawing a diagram of the relationship between words according to their use in a particular text. Semantic mapping has the effect of bringing relationships in a text to consciousness to deepen the understanding of a text and create associative networks for words. Through semantic mapping, students are stimulated to use their imagination to find a connection between words which help them to retain their schemata of the topics of the oral presentation. Semantic mapping is commonly used for various educational purposes, such as for increasing students' vocabulary mastery, for improving students' reading comprehension, for improving students' language skills, identifying the use structural organizations of texts, teaching critical thinking skills, and linking between reading and writing instruction. Another purpose of semantic mapping is to visually display the meaning-based connections between a word or phrase and a set of related words or concepts. Semantic mapping helps students, especially struggling students and those with disabilities, to identify, understand, and recall the meaning of words they read in the text. It is in line with Masters \& Mori (1993), who said that semantic mapping makes the students become independent learners in the sense that they learn by using their writer thinking.

There are several types of semantic mapping, for example, star diagram, spider diagram, fishbone map, cluster or cloud diagram, tree diagram, chain diagram, cycle diagram, and vocabulary map organizer. Students can choose any types of semantic mapping according to their preference. Semantic mapping is actually can be made with the integration of technology tools. There are websites which can help students in making semantic mapping, for example, Webspiration, Bubblus, Gliffy, Thinklinkr, Glinkr, Creately, Diagrammr, and Mindomo.

Many research has been conducted to investigate the use of semantic mapping in teaching a foreign language, especially reading skills. However, research on the use of semantic mapping in enhancing students' oral presentation skill is relatively unexplored. This paper filled the gap by describing how students perceive the implementation of semantic mapping in oral presentation skill class. One research question to reach the aim, was posed: How well do the students perceive the use of semantic mapping in their 
oral presentation class? This research questions will be the central point of the discussions in this paper.

\section{METHOD}

\section{Research Design}

In conducting this study, the researcher utilized a qualitative study as the framework of the research design. Specifically, this study was conducted within a case study setting. A case study can be defined as an empirical enquiry about a contemporary phenomenon or a case set within the real-world context especially when the boundaries between phenomenon and context are not clearly evident (Yin, 1994). Dornyei (2007) also defines a case study research as the study of the particularity and complexity of a single case. Miles and Huberman (1994) specifies the case here as a program, an institution, an organization, or a community.

The use of a case study research is assumed to give several benefits. Firstly, as case studies are qualitative in nature, thus they have the advantage of qualitative research. Johnson (1992) claims that a case study is primarily naturalistic, which relies on the collection of naturally occurring data. In other words, the data of a case study is high in reliability for the naturalness in terms of behaviour, environment and all related aspects of the events investigated. Yin (1994) also explains that in doing a descriptive case study, the researcher is able to retain the holistic and meaningful characteristics of real-life events. Zonabend (1992) in Tellis (1997) also explains that a case study research is done by giving special attention to completeness in observation, reconstruction, and analysis of the cases under study. In doing a case study research, a researcher must focus on a single entity as it exists in its natural environment (Johnson, 1992). McMillan and Schumacher (2001) also state that descriptive research using a descriptive model of inquiry describes an existing phenomenon by using numbers to characterize individuals or a group. It assesses the nature of existing conditions.

Qualitative research methods are used to examine questions that can best be answered by verbally describing how participants in a study perceive and interpret a various aspect of their environment (Crowl, 1996). Qualitative research provides opportunities for researchers to study social phenomena about people's everyday lives. 
Through a data interpretation process, qualitative research provides information about what, why and how a phenomenon in society happens which is in line with what Denzin and Lincoln (2005) say that qualitative research also involves an interpretive, naturalistic approach to the world. Yin (1994) also elaborates that employing qualitative method provides researchers with opportunities to represent the views and perspectives of the people/participants in a study.

\section{Research Site and Participant}

This research was conducted in IKIP Siliwangi Bandung. Thirty students of English Education Program were chosen as the participants of this research. The students joined Teaching English to Young Learners (TEYL) subject, which has two credit hours as the compulsory subject when they are in the second year of their study. There were 22 female students and eight male students. The age is between 17-22 years old. The exact percentage of the participant is summarized in Table 1 below:

Table 1: Profiles of Participant

\begin{tabular}{|c|c|c|c|}
\hline STUDENTS & AGE & $\boldsymbol{N}$ & $\boldsymbol{F}$ \\
\hline Female & $17-22$ years old & 22 & $73 \%$ \\
\hline Male & $17-20$ years old & 8 & $27 \%$ \\
\hline \multicolumn{2}{|c|}{ TOTAL } & 30 & $100 \%$ \\
\hline
\end{tabular}

\section{Research Instrument}

The instrument used in this research was a questionnaire. At the end of the learning process, students were given a questionnaire to assess how students perceive the use of semantic mapping in their TEYL class. The questionnaire was written online in Google form and distributed in a Whatsapp group of the chosen class. There are 5 in Likert form questions in the questionnaire. The specific questions in the questionnaire can be seen in Table 2 below:

Table 2: Questionnaire of students' perception on the use of semantic mapping

\begin{tabular}{|c|c|c|c|c|c|c|}
\hline \multirow{2}{*}{ NO } & \multirow{2}{*}{ QUESTIONS } & \multicolumn{5}{|c|}{ ANSWERS } \\
\hline & & SA & $\mathbf{A}$ & $\mathbf{N}$ & D & SD \\
\hline 1 & $\begin{array}{c}\text { SM can enhance students' quality of } \\
\text { information and organization }\end{array}$ & $\begin{array}{c}58 \% \\
(18 \mathrm{Ss})\end{array}$ & $\begin{array}{c}20 \% \\
(6 \mathrm{Ss})\end{array}$ & $\begin{array}{l}12 \% \\
(4 \mathrm{Ss})\end{array}$ & $\begin{array}{c}5 \% \\
(1 \mathrm{Ss})\end{array}$ & $\begin{array}{c}5 \% \\
(1 \mathrm{Ss})\end{array}$ \\
\hline 2 & $\begin{array}{c}\text { SM can enhance students' non- } \\
\text { verbal communication }\end{array}$ & $\begin{array}{c}51 \% \\
(16 \mathrm{Ss})\end{array}$ & $\begin{array}{l}23 \% \\
(7 \mathrm{Ss})\end{array}$ & $\begin{array}{l}14 \% \\
(5 \mathrm{Ss})\end{array}$ & $\begin{array}{c}6 \% \\
(1 \mathrm{Ss})\end{array}$ & $\begin{array}{l}6 \% \\
(1 \mathrm{Ss})\end{array}$ \\
\hline 3 & $\begin{array}{l}\text { SM can enhance the quality of verbal } \\
\text { communication }\end{array}$ & $\begin{array}{c}65 \% \\
(19 \mathrm{Ss})\end{array}$ & $\begin{array}{l}23 \% \\
(7 \mathrm{Ss})\end{array}$ & $\begin{array}{l}9 \% \\
(3 \mathrm{Ss})\end{array}$ & $\begin{array}{l}2 \% \\
(1 \mathrm{Ss})\end{array}$ & $\begin{array}{l}1 \% \\
(1 \mathrm{Ss})\end{array}$ \\
\hline 4 & Appropriate Use of Vocabulary & $\begin{array}{c}56 \% \\
(17 \mathrm{Ss})\end{array}$ & $\begin{array}{c}27 \% \\
(8 \mathrm{Ss})\end{array}$ & $\begin{array}{c}11 \% \\
(4 \mathrm{Ss})\end{array}$ & $\begin{array}{c}4 \% \\
(1 \mathrm{Ss})\end{array}$ & $\begin{array}{c}0 \% \\
(0 \mathrm{Ss})\end{array}$ \\
\hline
\end{tabular}




\section{Research Procedure}

In conducting this research, several procedures were done. For the first procedure, the teacher explained the syllabus of TEYL. It consisted of 8 topics to be presented by the students. The topics were arranged into eight weeks of meeting, and one meeting lasted for 100 minutes. It means that students learned TEYL for 800 minutes in total duration. When giving a presentation, students were asked to make semantic mapping based on the points of their oral presentation. Table 3 below explains the syllabus of TEYL:

Table 3: Syllabus of Teaching English to Young Learner (TEYL)

\begin{tabular}{|c|c|c|c|}
\hline MEETING & TOPICS & SOURCES & TECHNIQUES \\
\hline 1 & $\begin{array}{l}\text { Introduction to Course Syllabus, } \\
\text { Characteristics of Young Learners, } \\
\text { Theories of Children Learning } \\
\text { Development, TEYL in Indonesian } \\
\text { Context }\end{array}$ & $\begin{array}{c}\text { Syllabus } \\
\text { (Linse, 2005, pp.1-20) \& } \\
\text { (Musthafa, 2008, pp.2-3) }\end{array}$ & $\begin{array}{l}\text { KWL Chart } \\
\text { \& Lecturing }\end{array}$ \\
\hline 2 & $\begin{array}{l}\text { Topic 1: Teaching Listening to Young } \\
\text { Learners }\end{array}$ & (Linse, 2005, pp.21-44) & $\begin{array}{c}\text { Group } \\
\text { Presentation }\end{array}$ \\
\hline 3 & $\begin{array}{l}\text { Topic 2: Teaching Speaking to Young } \\
\text { Learners }\end{array}$ & (Linse, 2005, pp.45-67) & $\begin{array}{c}\text { Group } \\
\text { Presentation }\end{array}$ \\
\hline 4 & $\begin{array}{l}\text { Topic 3: Teaching Reading to Young } \\
\text { Learners }\end{array}$ & (Linse, 2005, pp.68-96) & $\begin{array}{c}\text { Group } \\
\text { Presentation }\end{array}$ \\
\hline 5 & $\begin{array}{l}\text { Topic 4: Teaching Writing to Young } \\
\text { Learners }\end{array}$ & (Linse, 2005, pp.97-119) & $\begin{array}{c}\text { Group } \\
\text { Presentation }\end{array}$ \\
\hline 6 & $\begin{array}{l}\text { Topic 5: Teaching Vocabulary \& } \\
\text { Grammar to Young Learners }\end{array}$ & $\begin{array}{c}\text { (Linse, 2005, pp.120- } \\
\text { 136) (Pinter, 2006, pp.83- } \\
\text { 97) }\end{array}$ & $\begin{array}{c}\text { Group } \\
\text { Presentation }\end{array}$ \\
\hline 7 & $\begin{array}{l}\text { Topic 6: Teaching English through } \\
\text { Songs, Chants \& Rhymes }\end{array}$ & $\begin{array}{l}\text { (Musthafa, 2008, p.19) \& } \\
\text { (Brewster et al, 2002, } \\
\text { pp.162-171) }\end{array}$ & $\begin{array}{c}\text { Group } \\
\text { Presentation }\end{array}$ \\
\hline 8 & $\begin{array}{c}\text { Topic 7: Teaching English through } \\
\text { Games }\end{array}$ & $\begin{array}{l}\text { (Musthafa, 2008, pp.12- } \\
\text { 19) \& (Brewster et al, } \\
\text { 2002, pp.172-185) }\end{array}$ & $\begin{array}{c}\text { Group } \\
\text { Presentation }\end{array}$ \\
\hline
\end{tabular}

Then, students' oral presentations were assessed based on four aspects: quality of information and organization, quality of non verbal communication, visual tools, appropriate use of terminology, as well as precision and details in document produced. 


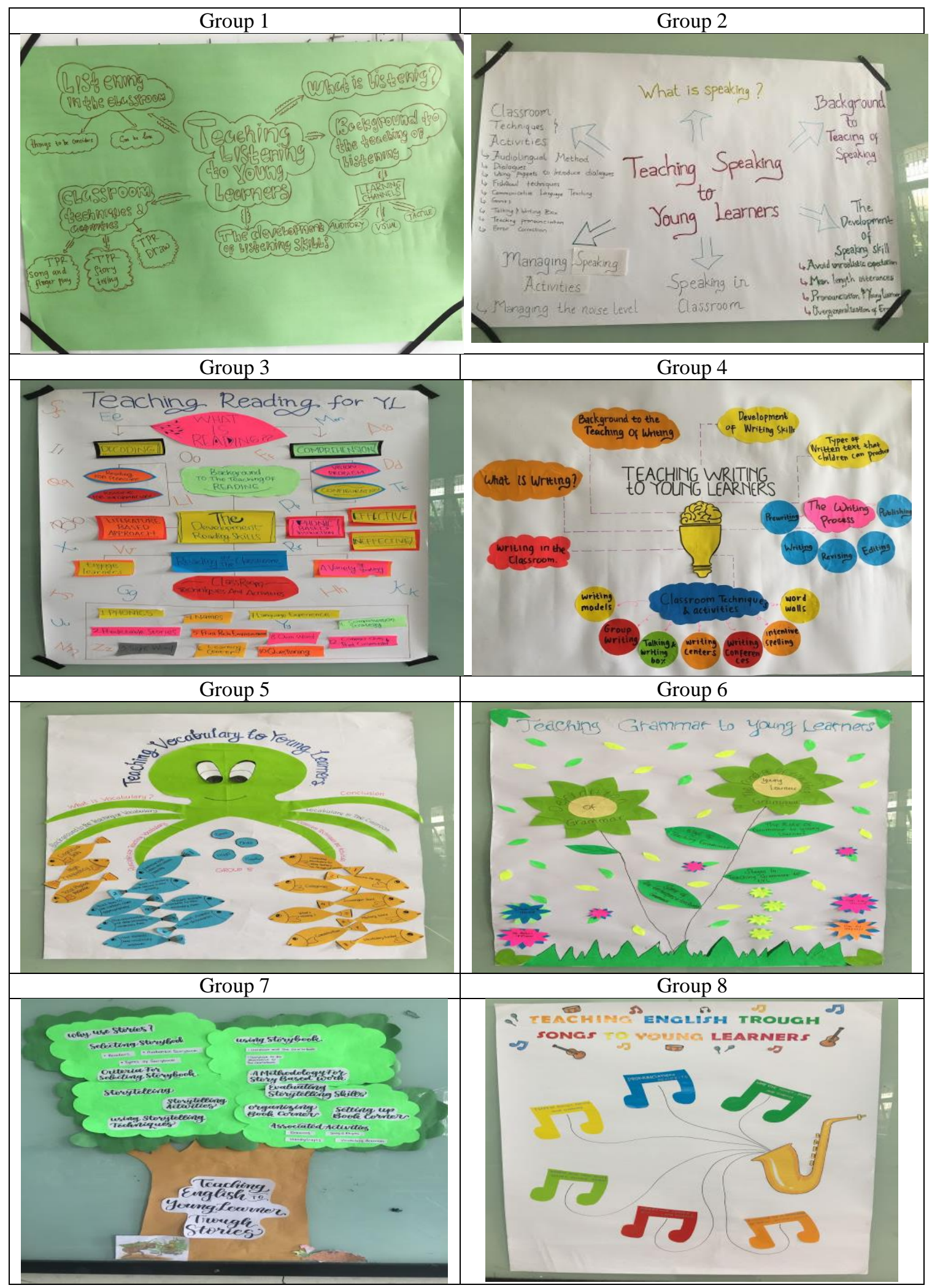

Figure 2: Semantic Mapping Made by Students 


\section{RESULT AND DISCUSSION}

The elaboration in this part deals with students' perception of the use of semantic mapping in enhancing students' oral presentation skills. An online questionnaire using Google Form was distributed to participants via Whatsapp group To gain information about the use of semantic mapping in learning TEYL. The result can be seen in several figures below.

The first aspect investigated is students' perception of the use of semantic mapping in enhancing their oral presentation skills in terms of organization and information quality. Students' answers can be seen clearly in the figure below:

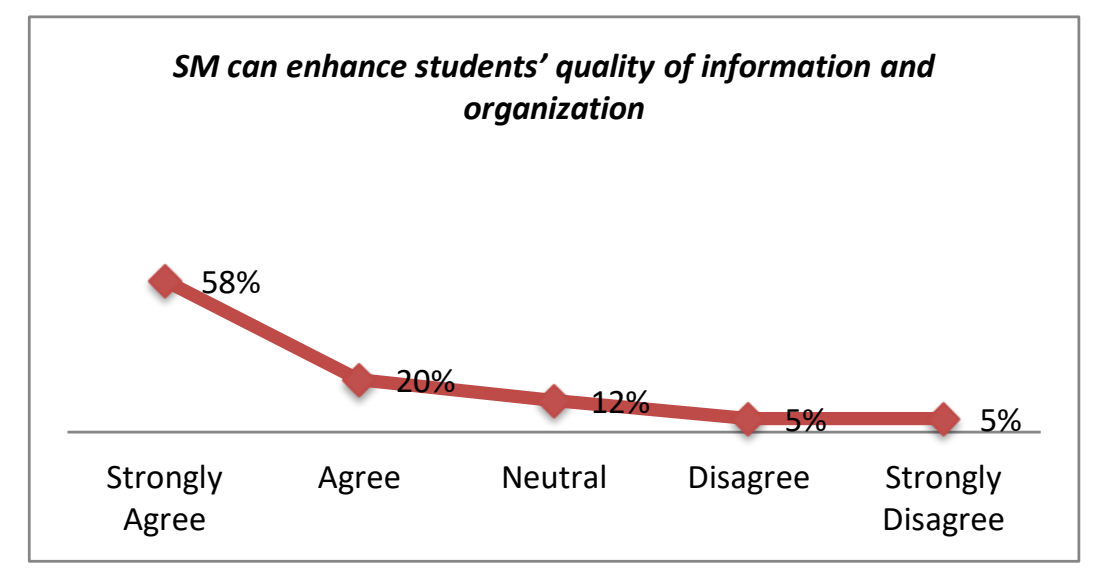

Figure 3: SM can enhance students' quality of information and organization

$58 \%$ or 18 students strongly agree that the use of semantic mapping in doing an oral presentation can help students to make information is directly linked to the topic of presentation. $20 \%$ or six students agree that semantic mapping can help students to organize the information in oral presentation effectively. $12 \%$ or four students say that they have no ideas about the use of semantic mapping in the oral presentation. Moreover, $10 \%$ or two students say that they prefer making presentation slides than making semantic mapping since it is easier to do. Some other students also say that they cannot draw nicely. From the chart above, it can be concluded that the majority of students perceive the use of semantic mapping in oral presentation skill class positively. They said that semantic mapping could help them to make the quality of information and organization presented better. The subsequent elaboration is related to the 
investigation of whether semantic mapping can enhance students' non-verbal communication skills. Figure 2 below describes the result:

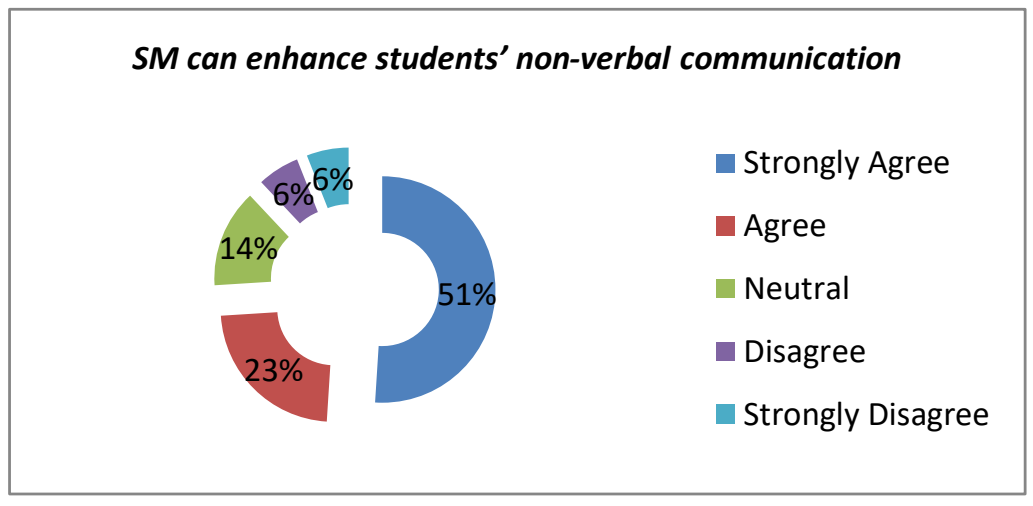

Figure 4: SM can enhance students' non-verbal communication

From the above figure, it can be seen that $51 \%$ or 16 students strongly agree that the use of semantic mapping can enhance their oral communication skill. They claim that it can make them more comfortable and confident when giving a presentation. By showing the semantic mapping, they can confidently maintain eye contact with the audience. $23 \%$ or seven students also agree that the use of semantic mapping can engage them with the audience by using body movement and gestures effectively. However, $12 \%$ or four students say that the use of semantic mapping creates some barriers during the oral presentation. The size of semantic mapping, which is not big enough, will create visual distraction among the audience. The next part deals with the investigation of whether semantic mapping can enhance the quality of students' verbal communication skills. Figure 3 below illustrates the result of the survey:

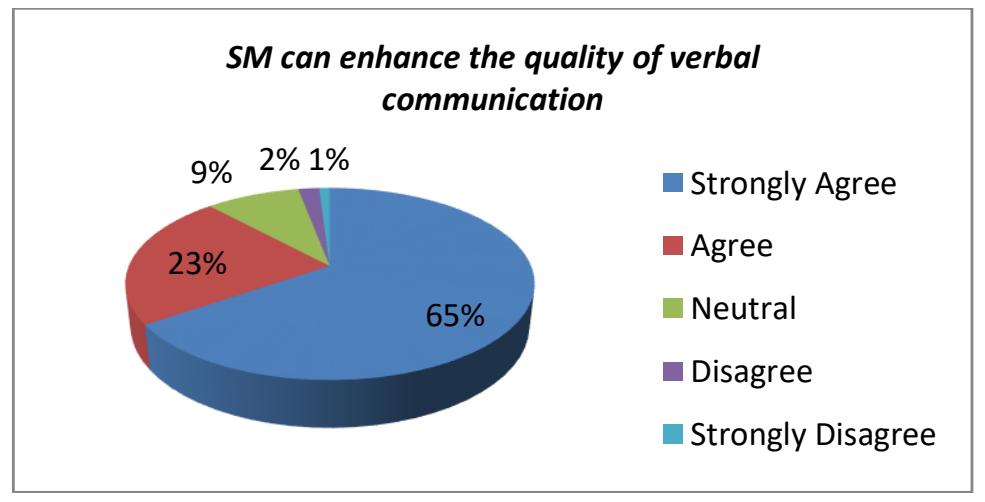

Figure 5: SM can enhance the quality of verbal communication 
Figure 3 above revealed that $65 \%$ or 19 students strongly agree that the use of semantic mapping can enhance the quality of their verbal communication skills. Students claim that they feel more confident in giving an oral presentation using semantic mapping, so their voice becomes robust, steady, and precise. $23 \%$ or seven students also say that semantic mapping can help them to consistently use inflections to emphasize critical points drawn in the semantic mapping or to create the interests of the audience. $9 \%$ or three students say that they have no ideas about the answer. Furthermore, $2 \%$ or one student says that the use of semantic mapping can create some barriers to verbal communication. Lack of precision, such as incorrect and unclear key words chosen in semantic mapping, can become the source of a misunderstanding of the topics of the oral presentation. The last part of the questionnaire reveals students' the perception of whether semantic mapping can help them to use vocabulary appropriately. Figure 4 below shows the result of the survey:

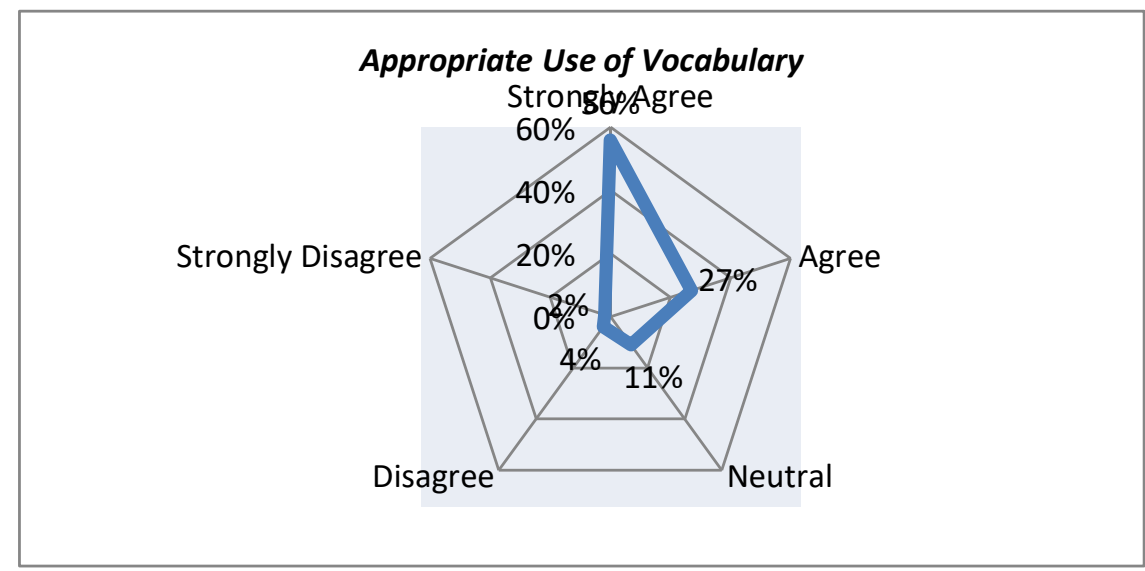

Figure 6: Appropriate Use of Vocabulary

From figure 4 , we see that $56 \%$ or 17 students say that by using semantic mapping, they could use appropriate vocabulary in giving an oral presentation. They said that semantic mapping could help them to deliver all terminologies used in the oral presentation in unique and creative ways. $27 \%$ or eight students also said that semantic mapping could help them to use vocabulary in the right context. 


\section{CONCLUSION}

To sum up, the result of the study reveals that the use of semantic mapping in the oral presentation is perceived positively by the students. The majority of the students believe that semantic mapping can help them to perform better in giving an oral presentation. Specifically, students perceive that semantic mapping has improved their oral presentation skill, in terms of organization and information quality, making information is directly linked to the topic of the presentation, maintaining eye contact with the audience, using body movement and gestures effectively, and using vocabulary in the right context. Therefore, students feel more confident in giving an oral presentation using semantic mapping, so their voice becomes robust, steady, and precise. In other words, students claim that using semantic mapping can help them to deliver all terminologies used in the oral presentation in unique and creative ways.

However, a small number of students claim that the use of semantic mapping creates some barriers during the oral presentation. The size of the semantic mapping they made, which is not big enough, created visual distraction among the audience. Moreover, lack of precision, such as incorrect and unclear key words chosen in semantic mapping, became the source of the misunderstanding of the topics of the oral presentation.

\section{Acknowledgement}

This study was supported by Belmawa Dikti of Indonesian Ministry of Research, Technology and Higher Education (Kementristek Dikti) under the Penugasan Dosen ke Sekolah (PDS) 2019 program.

\section{REFERENCES}

Denzin, N. K. and Lincoln, Y. (2005). Introduction: The discipline and practice of qualitative research. In Denzin, N. K. \& Lincoln, Y (Eds). The sage handbook of qualitative research ( $\left.2^{\text {nd }} e d\right)$. Thousand Oaks, California: Sage Publication.

Dornyei, Z. (2007). Research methods in applied linguistics: Quantitative, qualitative and mixed methodologies. Oxford: Oxford University Press.

Girrard, M. P. \& Trapp, P. (2011). An exploratory study of class presentations and peer evaluations: Do students perceive benefits? Academy of educational leadership journal. 15(1). pp. 77-94. 
Johnson, D. M. (1992). Approaches to research in second language learning. New York: Longman.

King, J. (2002). Preparing EFL learners for oral presentations preparing. Journal of Humanistic Studies, 4, 401-418. Hurford R. James dan Heasley B. 1983. Semantics: A Coursebook. Great Britain: Cambridge University Press.

Masters, M \& Mori. (1993). Semantic Mapping Technique. \{Accessed from: http://www.fatima.k12.nf.ca/semmap.htm

McMillan, J. H. \& Schumacher, S. (2001). Research in education: A conceptual introduction. New York: Longman.

Miles, W. L. \& Huberman, A. M. (1994). Qualitative data analysis (2 ${ }^{\text {nd }}$ edition. Thousand Oaks, California: Sage.

Morley, L. 2001. Producing new workers: Quality, equality and employability in higher education. Quality in higher education, 7(2), pp.131-138.

Murphy, H. A., Hildebrandt, H.W., \& Thomas, J.P. (1997). Effective business communications. 7thEdition, New York: McGraw-Hill.

Živković, S., \& Stojković, N. (2011). Modernization of English as foreign language studies in university. University Education in Transition.

Tellis, W. (1997). "Results of a case study on information technology at a university", The qualitative report. [on-line serial], Vol.3, No.4, \{Accessed from: http://www.nova.edu/ssss/QR/QR3-4/tellis3.html \}

Yin, R. K. (1994). Case study research design and methods (2 ${ }^{\text {nd }}$ edition). Thousand Oaks, California: Sage. 